Doc. dr. sc. Jakob Nakić, zamjenik županijske državne odvjetnice u Rijeci i docent Pravnog fakulteta Sveučilišta u Rijeci

\title{
STATUS DOMAĆEG PARNIČNOG PREDMETA DO DONOŠENJA ODLUKE SUDA EUROPSKE UNIJE U POVODU POSTAVLJENOG PRETHODNOG PITANJA*
}

\section{UVOD}

Naš zakonodavac odlučio se na propisivanje prethodnog postupka u posebnim procesnim zakonima, i to: Zakonu o kaznenom postupku, ${ }^{1}$ Zakonu o parničnom postupku ${ }^{2}$ i Zakonu o upravnim sporovima, ${ }^{3}$ pa tako i u odnosu na postavljanje prethodnog pitanja Sudu Europske unije (dalje: SEU). U teoriji postoje ozbiljne kritike na takav pristup kojima se mi u potpunosti priklanjamo. ${ }^{4}$

Zahtjev za prethodnu odluku mora se odnositi na: a) tumačenje ili b) valjanost prava Europske unije (dalje: EU), a ne na tumačenje pravila nacionalnog prava ili na činjenična pitanja iznesena u okviru postupka pred nacionalnim sudom. ${ }^{5}$

\footnotetext{
${ }^{*}$ Rad primljen 30. 10. 2018. godine.

Tekst je objavljen u izvornom obliku, bez lektorskih intervencija redakcije Glasnika $A K V$.

1 Narodne novine (dalje: NN) br. 152/08, 76/09, 80/11, 121/11, 91/12, 143/12, 56/13, 145/13, 152/14 (dalje: ZKP).

${ }^{2} \mathrm{NN}$ br. 53/91, 91/92, 58/93, 112/99, 88/01, 117/03, 88/05, 02/07, 84/08, 123/08, 57/11, 148/11, 25/13, 89/14 (dalje: ZPP).

${ }^{3} \mathrm{NN}$ br. 20/10, 143/12, 152/14, 94/16, 29/17 (dalje: ZUS).

${ }^{4}$ Pobliže vidi kod: Petrašević, T., Prethodni postupak pred Sudom EU, Pravni fakultet Sveučilišta u Osijeku, Osijek, 2014, 168. do 178.

5 Vidi odluku Vrhovnog suda Republike Hrvatske (dalje: VSRH), Rev-2553/15, od 13. listopada 2015, u kojoj je rečeno: „,...) da se nadležnost Suda Europske unije ne proteže na
} 
Nacionalni sud može SEU uputiti zahtjev za prethodnu odluku čim utvrdi da je za donošenje njegove presude potrebna odluka o tumačenju ili valjanosti prava EU.

Nacionalni sud koji upućuje zahtjev jasno i odvojeno navodi prethodna pitanja koja postavlja SEU. Pitanja moraju biti sama po sebi razumljiva, bez potrebe za upućivanjem na obrazloženje zahtjeva za prethodnu odluku. Nacionalni sud koji upućuje zahtjev također sažeto iznosi svoje stajalište o odgovoru koji treba dati na upućena prethodna pitanja.

Pod uvjetima predviđenima čl. 23.a Statuta SEU ${ }^{6}$ kao i člancima 105. do 114. Poslovnika SEU, ${ }^{7}$ zahtjev za prethodnu odluku u određenim okolnostima može biti podvrgnut ubrzanom ili hitnom postupku. O provedbi tih postupaka odlučuje SEU nakon što sud koji upućuje zahtjev podnese uredno obrazložen zahtjev u kojem su navedene pravne ili činjenične okolnosti koje opravdavaju primjenu tog postupka ili tih postupaka ili pak iznimno po službenoj dužnosti ako narav ili okolnosti predmeta to nalažu.

\section{PRAVNI OSNOV - UGOVOR O FUNKCIONIRANJU EUROPSKE UNIJE}

Čl. 267. Ugovora o funkcioniranju Europske unije ${ }^{8}$ propisuje: se tiču:

„Sud Europske unije nadležan je odlučivati o prethodnim pitanjima koja

(a) tumačenja Ugovorâ;

(b) valjanosti i tumačenja akata institucija, tijelâ, uredâ ili agencija Unije.

Ako se takvo pitanje pojavi pred bilo kojim sudom države članice, taj sud može, ako smatra da je odluka o tom pitanju potrebna da bi mogao donijeti presudu, zatražiti od Suda da o tome odluči.

Ako se takvo pitanje pojavi u predmetu koji je u tijeku pred sudom neke države članice, protiv čijih odluka prema nacionalnom pravu nema pravnog lijeka, taj je sud dužan uputiti to pitanje Sudu.

tumačenje i ocjenu zakonitosti nacionalnih propisa zemalja članica Europske unije. Stoga Vrhovni sud Republike Hrvatske nije ni bio ovlašten prije donošenja odluke o dopuštenosti revizije postaviti prethodno pitanje Sudu EU glede tumačenja odredbe čl. 91.a Zakona o parničnom postupku i ocjene valjanosti te odredbe." Vidi i Rev-2649/12, od 25. studenog 2014., dostupno na: http://www.vsrh.hr, stranica posjećena 26. lipnja 2017.

${ }^{6}$ Statut SEU dostupan je na: https://curia.europa.eu/jcms/upload/docs/application/pdf/201608/tra-doc-hr-div-c-0000-2016-201606984-05_00.pdf, stranica posjećena 26. lipnja 2017.

${ }^{7}$ Poslovnik SEU dostupan je na: https://curia.europa.eu/jcms/upload/docs/application/pdf/ 2016-10/tra-doc-hr-div-c-0000-2016-201608368-05_01.pdf, stranica posjećena 26. lipnja 2017.

${ }^{8}$ Vidi na: http://eur-lex.europa.eu/legal-content/HR/TXT/?uri=uriserv:OJ.C_.2016.202.01. 0001.01.HRV, dalje: UFEU. Stranica posjećena 26. lipnja 2017. 
Ako se to pitanje postavi u predmetu koji je u tijeku pred sudom neke države članice u pogledu osobe kojoj je oduzeta sloboda, Sud Europske unije djeluje u najkraćem mogućem roku."

Ono bitno za ukazati je da čl. 267. UFEU predviđa dvije mogućnosti kada nacionalni sudovi upućuju zahtjev za prethodno pitanje SEU, i to: a) kada sudovi imaju diskreciono pravo da se odluče za (ne)postavljanje prethodnog pitanja SEU, tj. da li je presuda SEU neophodna za donošenje odluke u predmetu pred nacionalnim sudom i b) kada su sudovi obvezni uputiti prethodno pitanje SEU a to je onda kada protiv odluka nacionalnih sudova nema pravnog lijeka. ${ }^{9}$

\section{DOMAĆI PROPISI}

\section{Ustav Republike Hrvatske}

Ukazujemo na odredbu čl. 145. Ustava Republike Hrvatske ${ }^{10}$

„Ostvarivanje prava koja proizlaze iz pravne stečevine Europske unije, izjednačeno je s ostvarivanjem prava koja su zajamčena hrvatskim pravnim poretkom.

Pravni akti i odluke koje je Republika Hrvatska prihvatila u institucijama Europske unije primjenjuju se u Republici Hrvatskoj u skladu s pravnom stečevinom Europske unije.

Hrvatski sudovi štite subjektivna prava utemeljena na pravnoj stečevini Europske unije.

Državna tijela, tijela jedinica lokalne i područne (regionalne) samouprave te pravne osobe s javnim ovlastima izravno primjenjuju pravo Europske unije."

Može se zaključiti da narečena odredba predviđa izravni učinak europskog prava u hrvatskom pravu.

${ }^{9}$ SEU je u predmetu Cilfit i dr. (283/81), od 6. listopada 1982. (ECLI:EU:C:1982:335) i Da Costa i dr. (28-30/62, ECLI:EU:C:1963:6) utvrdio tri iznimke kada sudovi protiv čijih odluka nema pravnog lijeka ne moraju postaviti prethodno pitanje SEU, a to su: a) kada bi se postavilo pitanje koje nije značajno za rješenje spora, b) kada odgovor na pitanje, neovisno kakav bio, ne može niti na koji način utjecati na ishod spora i c) kada se SEU, u drugim predmetima, već bavio postavljenim pitanjem pa čak i ako postavljena pitanja nisu potpuno identična (acte eclaire i acte clair). Tako u t. 10. narečene presude SEU je izrekao: „,...) ti sudovi nisu dakle dužni uputiti pitanje o tumačenju prava Zajednice koje se pred njima pojavilo ako pitanje nije bitno, tj. u slučaju kada odgovor na to pitanje, koje god ono bilo, ne bi mogao imati nikakav utjecaj na rješenje postupka."

${ }^{10} \mathrm{NN}$ br. 56/90, 135/97, 8/98, 113/00, 124/00, 28/01, 41/01, 55/01, 76/10, 85/10, 05/14, dalje: Ustav RH. 


\section{Zakon o sudovima}

U važećem Zakonu o sudovima ${ }^{11}$ ne nalazimo niti jednu odredbu koja bi bila posvećena postavljanju prethodnog pitanja domaćih sudova SEU.

ZS ima nekoliko odredaba posvećenih EU ali se one ne odnose na postavljanje prethodnog pitanja SEU.

Smatramo da bi se (i) u ZS-u trebalo naći mjesto za barem jednu odredbu koja bi regulirala institut prethodnog pitanja SEU kao i status predmeta koji se vodi pred nacionalnim sudom do donošenja odluke SEU. ${ }^{12}$

\section{Zakon o parničnom postupku}

Zakonom i izmjenama i dopunama Zakona o parničnom postupku ${ }^{13} \mathrm{u}$ čl. 213. st. 1. t. 2. unijeta je odredba da će sud prekinuti postupak ako je ,(...) odlučio podnijeti zahtjev Europskom sudu o tumačenju prava Europske unije ili o valjanosti akta koje su donijele institucije Europske unije."

\section{Zakon o kaznenom postupku}

U čl. 18. st. 3. do 5. ZKP-a propisano je:

„(3) Ako sud koji vodi postupak smatra da je za rješenje pitanja iz stavka 1. ovog članka potrebna odluka Suda Europske unije o tumačenju prava Unije ili o valjanosti akta kojega je donijelo njezino tijelo može podnijeti zahtjev Sudu Europske unije da donese odluku, o čemu će obavijestiti stranke.

(4) Ako se postupak vodi pred sudom protiv čije odluke nije dopuštena žalba, a taj sud smatra da je za rješenje pitanja iz stavka 1. ovog članka potrebna odluka Suda Europske unije o tumačenju prava Unije ili o valjanosti akta kojega je donijelo njezino tijelo podnijet će zahtjev Sudu Europske unije da donese odluku, o čemu će obavijestiti stranke.

(5) U slučaju iz stavka 3. i 4. ovog članka sud će prekinuti postupak do donošenja odluke Suda Europske unije. Za vrijeme trajanja prekida postupka sud može provoditi samo one radnje za koje postoji opasnost od odgode.”

Temeljem tog članka u praksi je donijeto rješenje: ${ }^{14}$

„Na temelju članka 18. stavak 5. Zakona o kaznenom postupku (,Narodne novine" broj 152/08, 76/09, 80/11, 91/12 - odluka Ustavnog suda, 143/12,

${ }^{11} \mathrm{NN}$ br. 28/13, 33/15, 82/15, 82/16, dalje: ZS.

${ }^{12}$ Smatramo da bi naš zakonodavac trebao ugledati na slovenski Zakon o sodiščih. Vidi infra točku 4. rada.

${ }^{13}$ NN. br. 57/11 (dalje: ZID ZPP/11) čl. 54. ZID ZPP/11.

${ }^{14}$ Županijski sud u Zagrebu, 5 K-US-29/15, od 30. svibnja 2017., neobjavljeno. Međutim, prethodno pitanje postavljeno je pod brojem Kv-EUN-25/16, od 16. svibnja 2017., a na SEU zaprimljeno pod brojem C-268/17 PPU. Dakle, u ovom slučaju prethodno pitanje nije postavio raspravni sudac već izvanraspravno vijeće. 
56/13, 145/13 i 152/14 - dalje u tekstu: ZKP/08), prekida se kazneni postupak protiv I optuženog I. S. zbog kaznenih djela iz članka 337. st. 4. KZ/97 u svezi članka 7. stavak 1. i članka 5. točka 13. Zakona o nezastarijevanju kaznenih djela ratnog profiterstva, pretvorbe i privatizacije i članka 347. stavak 1. KZ/97, te protiv II optuženog Z. T. H. zbog kaznenog djela iz članka 348. stavak 1. KZ/97, do donošenja odluke Suda Europske unije.”

\section{Zakon o upravnim sporovima}

\section{Čl. 45. stavak 2. ZUS-a određuje:}

„(2) Sud rješenjem može prekinuti spor:

1. dok se ne odluči o prethodnom pitanju ako je postupak o prethodnom pitanju pokrenut pred sudom ili nadležnim javnopravnim tijelom kao i kad sud odluči podnijeti zahtjev Sudu Europske unije o tumačenju prava Europske unije ili o valjanosti akta koje su donijele institucije Europske unije.“

\section{SLOVENSKI ZAKON O SODIŠČIH}

Zakon o sodiščih ${ }^{15}$ u čl. 213.a detaljno propisuje postupanje slovenskih sudova u postupku postavljanja prethodnog pitanja SEU. Tekst članka donosimo u hrvatskom prijevodu: ${ }^{16}$

„Ako odluka suda ovisi o rješavanju prethodnog pitanja radi razjašnjenja valjanosti ili tumačenja prava Europske unije, sud može donijeti rješenje kojim će prethodno pitanje dostaviti na odlučivanje Sudu Europske unije, u skladu s međunarodnim ugovorom kojim je Republika Slovenija prenijela izvršavanje djela suverenih prava na institucije Europske unije.

Ako je odluka Vrhovnog suda ili odluka drugoga suda, u postupku u kojem stranke u postupku ne mogu podnijeti redovan ili izvanredan pravni lijek, a radi razjašnjenja valjanosti ili tumačenja prava Europske unije, tada je Vrhovni sud odnosno drugi sud dužan donijeti rješenje, u skladu s međunarodnim ugovorom kojim je Republika Slovenija prenijela izvršavanje djela suverenih prava na institucije Europske unije.

Postupak u predmetu, u kojem je podnijet prijedlog iz prvog ili drugog stavka ovoga članka, sud će rješenjem prekinuti do prijema prethodne odluke, uz supsidijarnu primjenu zakona koji propisuje prekid postupak u predmetu, o

${ }^{15}$ Uradni list Republike Slovenije št. 94/07 - uradno prečiščeno besedilo, 45/08, 96/09, 86/10 - ZJNepS, 33/11, 75/12 - ZSPDSLS-A, 63/13, 17/15 in 23/17 - ZSSve, dostupno na: http:// www.pisrs.si/Pis.web/pregledPredpisa?id=ZAKO332, stranica posjećena 26. lipnja 2017.

${ }^{16}$ Sa slovenskog preveo autor. 
kojem sud odlučuje. Protiv rješenja o prekidu postupka nije dopušteno podnijeti redovni niti izvanredni pravni lijek.

Kada je sud prethodno pitanje uputio Sudu Europske unije, može shodnom primjenom zakona koji uređuje postupak u predmetu, u tom predmetu provoditi samo one procesne radnje i donositi samo one odluke koja ne trpe odlaganja ako nisu vezana za postavljeno prethodno pitanje odnosno koja ne dovršavaju odlučivanje u predmetu.

Ako sud više ne može primjenjivati odredbe koja je bila razlog za njegovo odustajanje od prethodnog pitanja, $i$ a ako još nije donesena odluka o prethodnom pitanju mora ustupljeno prethodno pitanje bez odlaganja povući, osim ako postoje zakonski razlozi za nastavak.

Odluka o prethodnom pitanju Suda Europske unije za sud je obvezujuća.

Sud dostavlja prijedlog prethodnog pitanja i odluku Suda Europske unije o prethodnom pitanju bez odlaganja na znanje Vrhovnom sudu."

\section{NAŠ PRIJEDLOG}

Uz to što se potpuno priklanjamo kritici pristupa našeg zakonodavca prethodnom pitanju SEU ${ }^{17}$ predlažemo da se:

- u budući Zakon o sudovima ugradi odredba koja će biti ista ili slična onoj koju

- sadrži slovenski Zakon o sodiščih, a vezano uz postavljanje prethodnog pitanja SEU,

- jasno propiše da pitanje SEU postavlja sudac i/ili vijeće a ne predsjednik suda,

- propiše kako spram rješenja o prekidu postupka nije dopušten niti redovni a niti

- izvanredni pravni lijek, ${ }^{18}$

- domaći sudovi, u što ranijem stadiju postupka, koriste institutom prethodnog

- pitanja SEU kada smatraju da im je mnijenje SEU potrebno u primjeni EU prava, ${ }^{19}$

\footnotetext{
${ }^{17}$ Vidi bilješku 4.
}

${ }^{18}$ SEU svoj stav o (ne)dopuštenosti pravnih lijekova spram odluke o upućivanju prethodnog pitanja nije jasno zauze. O tome vidi u predmetima 3/61 De Geus, [1962], ECR 45., 127/73, ECLI:EU:C:1974:25, C-210/06 Cartesio, ECLI:EU:C:2008:723. To pitanje je i različito riješeno u državama članicama EU.

19 ,„...) Na nacionalnom sudu je da odluči u kojoj fazi postupka je nužno uputiti prethodno pitanje." Vidi predmet: Fratelli Pardini SpA v. Ministero del Commercio con l'Estero and Banca Toscana, 338/85, EU:C:1988:194, t. 8. U predmetu Irish Cremery Sud je rekao kako odluka o tome u kojoj fazi postupka uputit pitanje ovisi o ,(...) razlozima procesne organizacije i učinkovi- 
- na web stranice Ministarstva pravosuđa i/ili VSRH postave Preporuke

- namijenjene nacionalnim sudovima koje se odnose na pokretanje prethodnog postupka, ${ }^{20}$

- Pravosudna akademija angažiranije prihvati edukacije sudaca svih sudova o institutu postavljanja prethodnog pitanja SEU. ${ }^{21}$

\section{NAMJESTO ZAKLJUČKA}

Znanost smatra da odluka SEU povodom prethodnog pitanja djeluje kao pravomoćno rješenje prethodnog pitanja, ${ }^{22}$ no, imajući na umu sudsku praksu $\mathrm{SEU}^{23}$ to mnijenje je očito pogrešno. Neki pravni pisci ${ }^{24}$ su mnijenja da odluke SEU o prethodnom pitanju djeluju erga omnes, ${ }^{25}$ odnosno da čak imaju snagu res iudicate. ${ }^{26}$

Može se postaviti pitanje što ako se nacionalni sud ne slaže s odlukom SEU o prethodnom pitanju?

U presudi $69 / 85$, od 5. ožujka 1986., ${ }^{27}$ a identično i u presudi C-466/00, od 6. ožujka 2003., ${ }^{28}$ SEU je izrekao:

tosti koje ocjenjuje nacionalni sud." Vidi spojene predmete: Irish Creamery Milk Suppliers Association and others v. Government of Ireland and others; Martin Doyle and others v. An Taoiseach and others C-36/80 i 71/80, EU:C:1981:62.

${ }^{20}$ Sada dostupna na: http://eur-lex.europa.eu/legal-content/HR/TXT/PDF/?uri=OJ:C: 2016: 439:FULL. Stranica posjećena 26. lipnja 2017.

${ }^{21}$ Da se po tom pitanju ipak nešto čini vidi na: https://www.pak.hr/clanak/poziv-za-prijave-na -seminar-prethodni-postupak-u-pravu-europske-unije-knigs-wusterhause-njemacka-2627-listopada-2017-22577.html, https://www.pak.hr/clanak/predavanje-suca-suda-europske-unije-i-profesora -na-pravnom-fakultetu-u-zagrebu-profdrsc-sinise-rodina-formulacija-prethodnog-pitanja-20286. html, https://www.pak.hr/clanak/poziv-za-prijave-na-seminar-prethodni-postupak-u-pravu-europske-unije-trier-1920-rujna-2016-14802.html, stranice posjećene 30. lipnja 2017.

${ }^{22}$ Rakić Vodinelić, V., Knežević, G., Građansko procesno pravo Evropske unije, Pravni fakultet Univerziteta u Beogradu, Beograd, 1998., 43.

${ }^{23}$ Vidi bilješke 25. i 26.

${ }^{24}$ Pescatore P., References for preliminary rulings under Article 177 of the EEC Treaty and Co-operation between the Court and National Courts, Luxembourg, Office for Official Publications on the European Communities, 1986, 10. i 24. Detaljnije vidi i u: Norberg A., Preliminary rulings and the co-operation between national and European Courts, magistarski rad, Pravni fakultet Sveučilišta u Lundu, Lund, 2005., dostupno na: https://lup.lub.lu.se/luur/download?func=downloadFile\&recordOId=1560676\&fileOId=1565389, stranica posjećena 26. lipnja 2017.

${ }^{25}$ Vidi spojene predmete: Amministrazione delle Finanze dello Stato v. Salumi, 66,127 i 128/79, EU:C:1981:270.

${ }^{26}$ Vidi predmet International Chemical Corporation v Amministrazione delle fianze dello Stato ECLI:EU:C:1981:102

${ }^{27}$ Wünsche Handelsgesellschaft GmbH \& Co. v Federal Republic of Germany, predmet 69/85, EU:C:1986:104.

${ }^{28}$ Vidi predmet C-466/00, od 6. ožujka 2003., na: ECLI: ECLI:EU:C:2003:127. Identično i u predmetu C-634/15, od 30. lipnja 2016. ECLI: ECLI:EU:C:2016:510. 
„(...) Ponajprije, treba podsjetiti da autoritet presude donesene povodom zahtjeva za prethodnu odluku ne sprečava nacionalni sud kojemu je upućena ta presuda da se prije donošenja odluke u glavnom postupku ponovno obrati Sudu ako to smatra potrebnim. Takvo pravno sredstvo može biti opravdano kada nacionalni sud ima poteškoća $s$ razumijevanjem ili primjenom presude, kada postavi Sudu novo pravno pitanje te kad mu podnese nove elemente za razmatranje koji bi mogli navesti Sud da drukčije odgovori na ranije postavljeno pitanje (rješenje od 5. ožujka 1986., Wünsche, 69/85, EU:C:1986:104, t. 15.; presude od 11. lipnja 1987., X, 14/86, EU:C:1987:275, t. 12. i od 6. ožujka 2003., Kaba, C-466/00, EU:C:2003:127, t. 39.)".

Zaključno ukazujemo na stav Jacquea i Weilera ${ }^{29}$ koji smatraju da je institut prethodnog pitanja postupak kojim europsko pravo postaje dio pravne kulture i nacionalnog prava država članica EU i kojim nacionalni sudovi mogu (is) koristiti pravo ili obvezu koja im je dana europskim pravom. Smatraju da je odredba o prethodnom pitanju instrument integracije par excellence.

Na kraju valja ukazati da odlukom SEU o prethodnom pitanju nije (oba) vezan samo nacionalni sud koji je pitanje postavio, već i svi nacionalni sudovi koji budu odlučivali u kasnijim fazama u tom predmetu. ${ }^{30}$

${ }^{29}$ Jaque J.P., Weiler, J.H.H., On the Road to European Union - A New Judicial Architecture: An Agenda for the Intergovernmental Conference, Common Market Law Review, 27, (1990), str. 185. do 207.

${ }^{30}$ Lenaerts K., Arts D., Maselis I., Procedural Law of the European Union, Sweet \&Maxwell, London, 2006., 193. 